\title{
DOI: $10.22616 /$ j.balticsurveying.2020.003 \\ CREATION OF MANAGEMENT ZONES FOR THE PURPOSES OF LAND DEVELOPMENT AT THE IMPLEMENTATION OF PRECISION FARMING IN BELARUS
}

\author{
(iD) Kutsayeva Alesia, Myslyva Tamara, \\ Belarussian State Agricultural Academy
}

\begin{abstract}
Improving the methodology of on-farm land management in the direction of transition from the formation of work sites to the formation of management zones for the specific requirements of the agricultural producer upon implementation of precision farming is extremely important for the agricultural sector of the Belarusian economy. The article presents the results of applying the methods of geostatistical and multifactor geoinformation analysis for the formation of management zones within the limits of land use of RUE "Uchkhoz BGSHA" (Republic of Belarus, Mogilev region, Gorky district). The total area of the surveyed territory is 83420.1 hectares. The nature of the spatial distribution of data on the content of humus, mobile phosphorus and potassium in the soil as well as $\mathrm{pH}$ level was estimated using the tools of the Spatial Statistics module of ArcGIS version 10.5. The presence of reliable clustering of data on soil parameters was established, since the value of the global Moran index I ranged from 0.197827 to 0.360388 , and the z-score in all cases exceeded 2.58. The universal kriging method turned out to be the most suitable for modeling the spatial distribution of soil $\mathrm{pH}$ data, while the empirical Bayesian kriging method is the most acceptable when modeling the spatial distribution of the content of humus, phosphorus, and potassium in the soil. The method of principal components and the simple summation of rasters using a calculator proved to be suitable for identifying management zones by a set of soil parameters (the discrepancy with the actual area was 16.56 and 16.24 ha, respectively).
\end{abstract}

Key words: geospatial analysis, soil, management zones, clustering, precision farming.

\section{Introduction}

Due to the impact of globalization, agriculture has to face a number of serious problems, in particular, climate change, growing demand for energy resources and their deficit, accelerated urbanization, aging population in rural areas, and increased competition in world markets. With regard to land resources, the primary problem, relevant to the EU countries as well as to Belarus and other neighbouring countries, is the loss of agricultural land area. Decreasing of arable lands in Europe is on average $0.7 \%$ per year over the last decade (Daheim at all, 2016), and according to forecast estimates will reach $1.12 \%$ by 2030 (EU agricultural outlook, 2018) while in Belarus this indicator reaches $0.1-0.4 \%$ (Agriculture of the Republic..., 2019). Given the constant rise in the cost of energy resources and raw materials for the production of mineral fertilizers, as well as shortage of organic fertilizers, the problem of identifying the ways of increasing the economic efficiency of land use is becoming extremely urgent. The introduction of accurate (coordinate) farming as a modern concept of agricultural management using digital methods to monitor and optimize agricultural production processes is one of the methods for its successful solution (Doerge, 1999; GIS for Housing..., 2003). Its ultimate goal is to increase the quantity and quality of agricultural products obtained with less energy consumption and inputs, as well as to reduce the negative impact on the environment. The world market of precision farming technologies averages 2.3 billion euros and is expected to increase by an average of $12 \%$ every year (Zarco-Tejada at all, 2014).

Belarus has high potential for the introduction of precision farming systems or their separate elements in agricultural production. Among its main advantages is the existence of over 1380 agricultural enterprises with an average land use of more than 5.3 thousand hectares of agricultural land and over 3.5 thousand hectares of arable land (Agriculture of the Republic..., 2019). Also, a positive factor which should be taken into consideration is the concentration of agricultural land mainly in the state ownership (87.6\% of the total area), which opens up the opportunities for agricultural producers to receive government financial support for the implementation of precision farming systems, in particular for the modernization of technological processes and the purchase of high-precision equipment.

However, along with the advantages, there are problems that impede the widespread adoption of precision farming systems in agricultural enterprises. The most important of them is the existing system of on-farm land management, focused on traditional energy and resource-intensive farming and ignoring the existing heterogeneities within a single field or land - the key factors for coordinate 
farming. In particular, the formation of work sites without taking into account the spatial heterogeneity of both the soil cover and the agrochemical and physicochemical properties of soils excludes the economic benefits of precision farming, such as the reduction of the financial and energy costs of agricultural production without reducing its volume. Accurate determination of the areas of heterogeneity within the field is an essential condition for the effective implementation of coordinate farming. Its successful implementation, in turn, is possible exclusively by using the possibilities of GIS analysis (Bateman at all, 2002; Mitchell, 2005; Myslyva, Bejyavskij, 2019). It is used both for the search of spatial patterns in the distribution of particular soil indicators and the relationships between them, and the development of methods to create relevant maps suitable for use on agricultural machines equipped with global positioning systems.

A number of studies have been undertaken to study the possibilities of geospatial analysis in various fields of the national economy. In particular, works (Barliani, 2016; Kaganovich, 2017; Chymyrov, Bekturov, 2018) are devoted to the use of GIS analysis in territorial planning, researches (Perkins at all, 2009; Kurowska at all, 2018) are dedicated the use of geospatial analysis for housing and urban development, works (Baklanov at all, 2010; Bogodyazh, 2019) - the GIS capabilities applied in the economy of environmental management. Considerable research in recent years has been devoted directly to the delineation of management zones for precision farming (Nawar at all, 2017; Behera at all. 2018; Mohamed at all, 2019; Edge, 2019). However, issues related to the methodology for implementing on-farm land management measures and the application of GIS functionality in the transition to precision farming technologies were not in the focus of attention of Belarussian scientistseconomists and land surveyors. Improving the methods of on-farm land management for the transition from the formation of work sites to the formation of management zones according to the specific requirements of the agricultural producer are also underdeveloped.

All of the above indicates that the development of new approaches to on-farm land management in the process of introducing a precision farming system is extremely relevant to the agricultural sector of the Belarusian economy and requires a detailed comprehensive study.

\section{Methodology of research and materials}

The purposes of this study were to estimate the spatial distribution of agrochemical and physicochemical properties of soils for the formation of management zones when introducing elements of the precision farming system as well as to identify areas with the most optimal agrochemical indicators by performing multivariate analyzes in the GIS environment.

The studies were carried out on the territory of Gorky district of Mogilev region (Republic of Belarus) within the land use of RUE "Uchkhoz BGSHA" on an area of 8342.1 thousand hectares (Fig. 1).

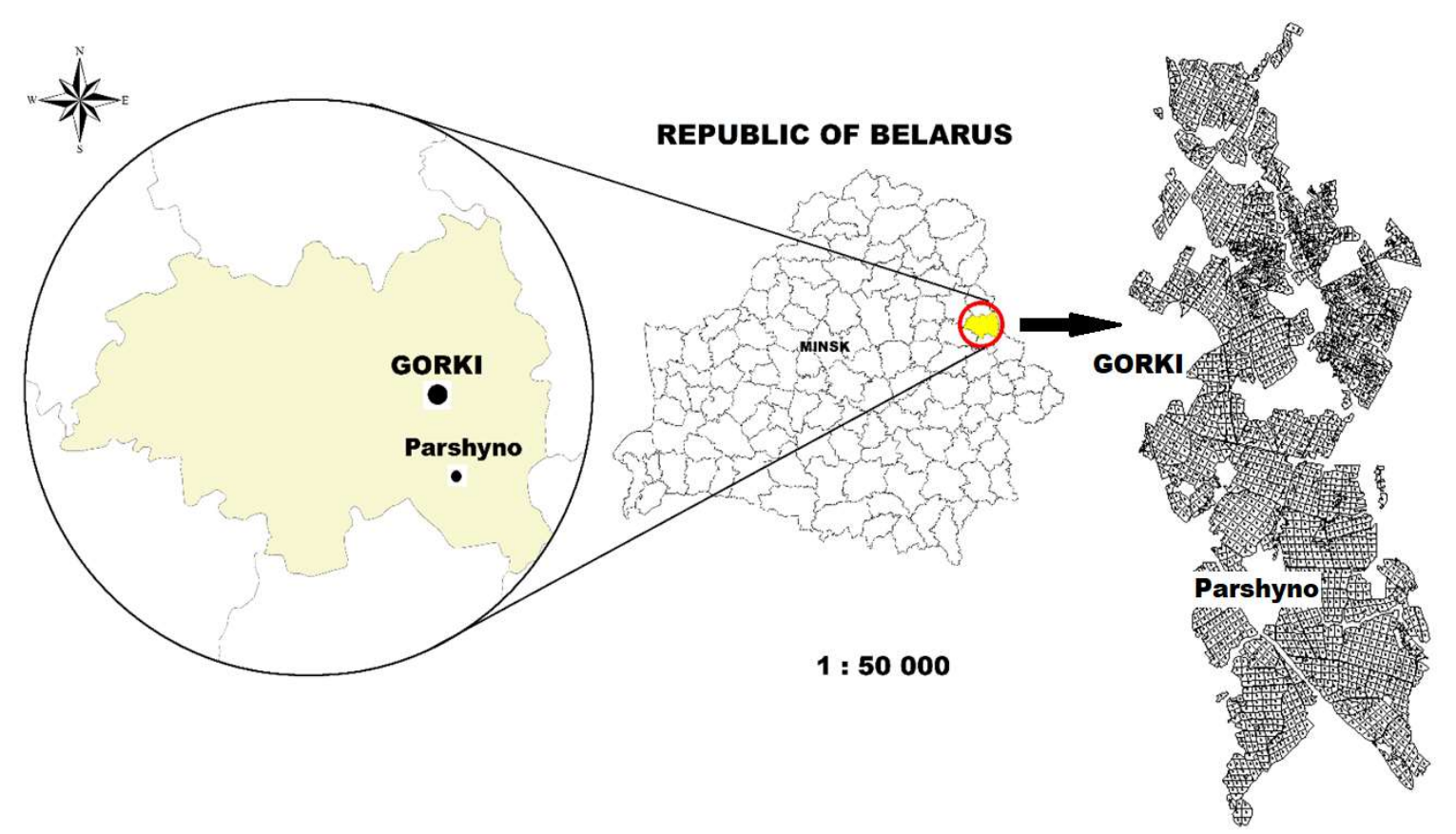

Fig. 1. The location of studied territory 
The data obtained from the agrochemical survey of the territory of RUP "Uchkhoz BGSHA", executed in 2018 by the Mogilev Regional Design and Exploration Station of Agrochemicalization were used for the analysis. The soil cover of the study area is represented by Sod-podzolic, Umbric Retisols (WRB, 2016); Eutric Podzoluvisol (FAO, 1988).

The spatial distribution analysis was performed using the functionality of the Spatial Statistics Tools of ArcGIS version 10.5 for the following agrochemical and physicochemical soil properties: soil solution reaction $\left(\mathrm{pH}_{\mathrm{KCl}}\right)$; the content of humus, mobile phosphorus and potassium. Information on the main statistical characteristics of the samples of the source data are presented in Table 1.

Table 1

Statistical characteristics of a sample of data on agrochemical and physicochemical indicators used to perform geostatistical analysis

\begin{tabular}{|l|c|c|c|c|c|c|c|c|}
\hline \multirow{2}{*}{$\begin{array}{c}\text { Indicator name and } \\
\text { sample size }\end{array}$} & \multicolumn{3}{|c|}{ Indicator value } & \multirow{2}{*}{ Sd } & $\begin{array}{c}\text { Cv, } \\
\text { \% }\end{array}$ & Med & Kurtosis & Skewness \\
\cline { 2 - 9 } & $\min$ & $\max$ & mid & & & & \\
\hline $\mathrm{pH}_{\mathrm{KCl}}, \mathrm{n}=1622$ & 4.16 & 6.90 & 5.83 & 0.56 & 9.6 & 5.94 & 2.87 & -0.71 \\
\hline $\mathrm{Humus,} \%, \mathrm{n}=1636$ & 1.02 & 4.04 & 2.14 & 0.62 & 28.9 & 2.0 & 4.08 & 1.10 \\
\hline $\mathrm{P}_{2} \mathrm{O}_{5}, \mathrm{mg} / \mathrm{kg}, \mathrm{n}=1630$ & 40 & 426 & 208 & 95.7 & 46.4 & 192 & 2.11 & 0.36 \\
\hline $\mathrm{K}_{2} \mathrm{O}, \mathrm{mg} / \mathrm{kg}, \mathrm{n}=1634$ & 41 & 401 & 217 & 95.7 & 44.1 & 203 & 2.28 & 0.45 \\
\hline
\end{tabular}

Note: Sd is the standard deviation; $\mathrm{Cv}$ is the coefficient of variation; Med is the median.

The global Moran (I) index was calculated by the formula (1) (Mitchell, 2005):

$$
\mathrm{I}=\frac{n \sum_{i=1}^{n} \sum_{j=i}^{n} w_{i j}\left(y_{i}-\bar{y}\right)\left(y_{j}-\bar{y}\right)}{\left[\sum_{i=1}^{n} \sum_{j=i}^{n} w_{i j}\right]\left[\sum_{i=1}^{n}\left(y_{i}-\bar{y}\right)^{2}\right]}
$$

Where $n$ denotes the number of units in the sample,

$w_{j i}$ denotes the weight of the spatial relationship between the $i$-th and $j$-th sampling units,

$y_{i}$ denotes the attribute value for the $i$-th sample unit,

$\bar{y}$ denotes the sample mean value of the attribute.

The Getis-OrdGi * index value was counted using the formula (2) (Mitchell, 2005):

$$
\text { Getis-OrdGi } *=\frac{\sum_{j=1}^{n} w_{i, j} x_{j}-\bar{X} \sum_{j=1}^{n} w_{i, j}}{\sqrt{\frac{\left[n \sum_{j=1}^{n} w_{i, j}^{2}-\left(\sum_{j=1}^{n} w_{i, j}\right)^{2}\right]}{n-1}}}
$$

Where $x_{j}$ denotes the attributive value of the object of observation,

$w_{i, j}$ denotes spatial weight between objects $i$ and $j$,

$n$ denotes the total number of objects.

Semivariograms were used as the main tool for studying the structure of the spatial distribution of agrochemical indicators. Based on the regional theory of variations and internal hypotheses, the semivariogram is expressed as follows (3) (Myslyva at all, 2018):

$$
\gamma(\mathrm{h})=\frac{1}{2 N(h)} \sum_{i=1}^{N(h)}\left[Z\left(x_{i}\right)-Z\left(x_{i}+h\right)\right]^{2}
$$

Where $\gamma(\mathrm{h})$ denotes semi-variant,

$h$ denotes the lag interval,

$Z$ denotes soil property parameter,

$N(h)$ denotes the number of pairs of places separated by the distance lag $h$,

$z\left(x_{i}\right)$ and $z\left(x_{i}+h\right)$ denotes the values of $Z$ at the positions $x_{i}$ and $x_{i}+h$.

The interpolation accuracy was determined from the mean error (ME), mean square error (RMSE) and standard error RMSS (3), (4), (5): 
Where $O_{i}$ denotes the observed value,

$$
\begin{aligned}
& \mathrm{ME}=\frac{\sum_{i=1}^{N}\left(O_{i}-S_{i}\right)}{N} \\
& \mathrm{RMSE}=\sqrt{\frac{\sum_{i=1}^{N}\left(O_{i}-S_{i}\right) 2}{N}} \\
& \mathrm{RMSS}=\frac{R M S E}{\Delta}
\end{aligned}
$$

$S_{i}$ denotes the predicted value,

$N$ denotes the sample size,

$\Delta$ denotes the range equal to the difference between the maximum and minimum observable values.

Multivariate data analysis was used for the most accurate determination of land parcels location with low, satisfactory, good and excellent quality.

\section{Discussion and results}

Precision farming management zone is defined as "a sub-region of a field that expresses a functionally homogeneous combination of yield-limiting factors for which a single rate of a specific crop input is appropriate" (Doerge, 1999; Edge, 2019). Today, there are mainly two approaches to the definition of management zones:

1) the fields which are divided into control zones in accordance with the values of one or more characteristics of the soil or crop;

2) management zones which are determined by the value of the return on the cost of the yield (Roudier at all, 2008).

It should be noted that since the elements of precision farming technology have just begun to be introduced in Belarus, the application of the approach based on economic characteristics is not possible. However, the definition of management zones based on soil parameters and yield indicators also has a number of limitations. In particular, today there is a small number of combines equipped with devices for accurate crop accounting at the agricultural enterprises of Belarus. Due to this, the soil parameters most often used by the agronomic services of agricultural enterprises were selected as initial indicators for the development of methods to determine management zones in conditions of the Republic of Belarus. Such indicators include the content of humus, mobile phosphorus and potassium, as well as the $\mathrm{pH}$ of the soil solution.

At the first stage of research, data were grouped using the k-means algorithm. The purpose of this grouping was to find out natural clusters and to distribute data on soil parameters to a given number of groups in which all indicators are most similar to each other, while the groups themselves are as different as possible (Table 2).

\begin{tabular}{|c|c|c|c|c|}
\hline \multirow{2}{*}{$\begin{array}{l}\text { Identified } \\
\text { group of } \\
\text { indicators }\end{array}$} & \multicolumn{4}{|c|}{ Indicator name } \\
\hline & рНксl & $\mathrm{P}_{2} \mathrm{O}_{5}, \mathrm{mg} / \mathrm{kg}$ & $\mathrm{K}_{2} \mathrm{O}, \mathrm{mg} / \mathrm{kg}$ & Humus, \% \\
\hline 1 & 0,5857 & 0,6634 & 0,8721 & 0,5331 \\
\hline 2 & 0,5086 & 0,8960 & 0,9514 & 0,9901 \\
\hline 3 & 0,5257 & 0,6881 & 1,0000 & 0,9901 \\
\hline 4 & 0,6886 & 0,9282 & 0,7289 & 0,6225 \\
\hline Overall value & 0,6166 & 0,5782 & 0,4573 & 0,4460 \\
\hline
\end{tabular}

Table 2

$\mathrm{R}^{2}$ value for identified groups of indicators

The value of $\mathrm{R}^{2}$ indicates that the dominant indicator in determining group 1 is the content of mobile potassium $\left(R^{2}=0.87\right)$, group 2 - the content of humus $\left(R^{2}=0.99\right)$, group 3 - the content of mobile potassium $\left(\mathrm{R}^{2}=1.0\right)$, group 4 - the content of mobile phosphorus $\left(\mathrm{R}^{2}=0.93\right)$. Group 3 having a maximum area of the selected clusters is 2703.5 ha; groups 1 and 2 are relatively equal in area size 2182.9 and 2059.3 hectares correspondingly, and group 4 has a minimum cluster area - 1396.4 hectares.

After clusters had been established, the spatial autocorrelation measure was estimated through the determination of the Moran index. The calculated value of the global Moran I index ranged from 0.197827 to 0.360388 ; therefore, the data on the agrochemical and physical-chemical properties of the soil in the study area are not randomly distributed and clustered. Since the magnitude of the z-score in 
all cases exceeded 2.58 , it can be argued with a $99 \%$ probability that the clustered type of data distribution is not random.

"Hot Spot Analysis" was performed to establish the reliability of clustering data with high and low values. It was performed by determining the magnitude of the overall Getis-Ord $\mathrm{Gi} *$ index, a statistical indicator calculated for each feature in the data set. This information allows to visually identify where, within the study area, the maximum and minimum values of the studied soil properties will be observed, and also approximately indicate the possible localities of the defined management zones.

The analysis of clusters and outliers identifies the concentrations of high values, low values and spatial outliers of data on the agrochemical and physical-chemical properties of the soil. As a result it becomes possible to find out 1) where the clearest boundaries between the contours with a high and low content of a particular element in the soil pass; 2) whether there are abnormally high or abnormally low values of indicators that can be attributed to spatial outliers within the study area. The availability of the maximum amount of outliers with high values was established for the data on the phosphorus content (84 clusters), the data on the content of humus were characterized by the maximum number of outliers with low values (135 clusters), and the data on $\mathrm{pH}$ level were characterized by the minimum number of outliers (Table 3 ).

Table 3

Identified outliers verification results

\begin{tabular}{|l|c|c|c|c|c|c|}
\hline \multirow{2}{*}{$\begin{array}{c}\text { Indicator name and } \\
\text { sample size }\end{array}$} & \multicolumn{2}{|c|}{$\begin{array}{c}\text { Number of checked } \\
\text { outliers, pcs }\end{array}$} & \multicolumn{2}{c|}{$\begin{array}{c}\text { Number of confirmed } \\
\text { outliers, pcs }\end{array}$} & \multicolumn{2}{c|}{$\begin{array}{c}\text { Discrepancy of } \\
\text { outliers, \% }\end{array}$} \\
\cline { 2 - 7 } & $\mathrm{HL}$ & $\mathrm{LH}$ & $\mathrm{HL}$ & $\mathrm{LH}$ & $\mathrm{HL}$ & $\mathrm{LH}$ \\
\hline $\mathrm{pH} \mathrm{KCl}_{\mathrm{KC}}, \mathrm{n}=1622$ & 57 & 46 & 19 & 17 & 67 & 62 \\
\hline $\mathrm{Humus}, \%, \mathrm{n}=1636$ & 56 & 135 & 12 & 34 & 78 & 75 \\
\hline $\mathrm{P}_{2} \mathrm{O}_{5}, \mathrm{mg} / \mathrm{kg}, \mathrm{n}=1630$ & 84 & 78 & 52 & 17 & 38 & 78 \\
\hline $\mathrm{K}_{2} \mathrm{O}, \mathrm{mg} / \mathrm{kg}, \mathrm{n}=1634$ & 59 & 89 & 32 & 22 & 45 & 75 \\
\hline
\end{tabular}

Note: $\mathrm{HL}$ - cluster with high outliers; $\mathrm{LH}$ - cluster with low outliers

Spatial emissions in our case are due to both the imperfection of the soil sampling methodology and the imperfection of the applied methods of mapping the results of agrochemical studies. On the other hand, the presence of emissions may be connected with the objective factors, for example, the use of various doses of mineral fertilizers within certain areas. This, in particular, can explain the variegated spatial distribution of mobile phosphorus and potassium.

In our opinion, it is necessary to carry out an additional examination to clarify the situation when detecting emission sites. The results of such recheck indicated that from 38 to $78 \%$ of clusters with high outliers and from 62 to $78 \%$ of clusters with low data outliers were not confirmed. Subsequently, the areas with unconfirmed spatial outliers were excluded from the data set during the further modeling of the spatial distribution of the particular indicator by interpolation method.

Kriging interpolation was used to model the spatial distribution of data (Table 4). The universal kriging method turned out to be the most suitable for modeling the spatial distribution of soil $\mathrm{pH}$ data, which is consistent with the results obtained in (Mohamed at all, 2019). The empirical Bayesian kriging method turned out to be the most acceptable when modeling the spatial distribution of the content of humus, phosphorus, and potassium in the soil, which also correlates with the results presented in (Samsonova at all, 2017; Durdević at all, 2019).

Table 4

The study area soil properties semivariogram parameters

\begin{tabular}{|l|c|c|c|c|c|c|}
\hline \multicolumn{1}{|c|}{ Variable } & Model & Nugget & Slope & Power & ME & MSSE \\
\hline $\mathrm{Humus}, \%$ & Power & $3.92 \cdot 10^{-2}$ & $1.03 \cdot 10^{-2}$ & 1.61 & 0.001 & 0.929 \\
\hline $\mathrm{P}_{2} \mathrm{O}_{5}, \mathrm{mg} / \mathrm{kg}$ & Power & $5.26 \cdot 10^{3}$ & $5.92 \cdot 10^{3}$ & 1.54 & 0.136 & 0.965 \\
\hline $\mathrm{K}_{2} \mathrm{O}, \mathrm{mg} / \mathrm{kg}$ & Power & $1.71 \cdot 10^{2}$ & $4.35 \cdot 10^{3}$ & 1.52 & 0,166 & 0,953 \\
\hline $\mathrm{pH} \mathrm{K}_{\mathrm{KCl}}$ & Spherical & 0.000 & $0.318^{*}$ & $0.318^{* *}$ & 0.002 & 1.007 \\
\hline
\end{tabular}

Note: ${ }^{*}$ - partial sill; ${ }^{* *}$ - sill

The next stage of the research was the search for the most acceptable method for determining zones with the best and worst set of studied indicators of soil quality. Multifactor analysis for searching the optimal agrochemical land parcels was carried out in three ways: 1 - analysis using the functionality 
of the Raster Calculator tool; 2 - analysis using the Principal Components Method; 3 - Maximum Likelihood Classification, using classification with training. As a result of multifactor analysis, three resulting images were obtained by the methods described above. It should be noted that when using the method of principal components, the content of humus in the soil and the $\mathrm{pH}$ of the soil solution is $72.3 \%$ of the total variability of the data, therefore, if there is insufficient information about the soil parameters, they can be primarily used to identify areas of heterogeneity (Table 5).

Table 5

Principal component analysis of soil properties and loading coefficient for the principal components

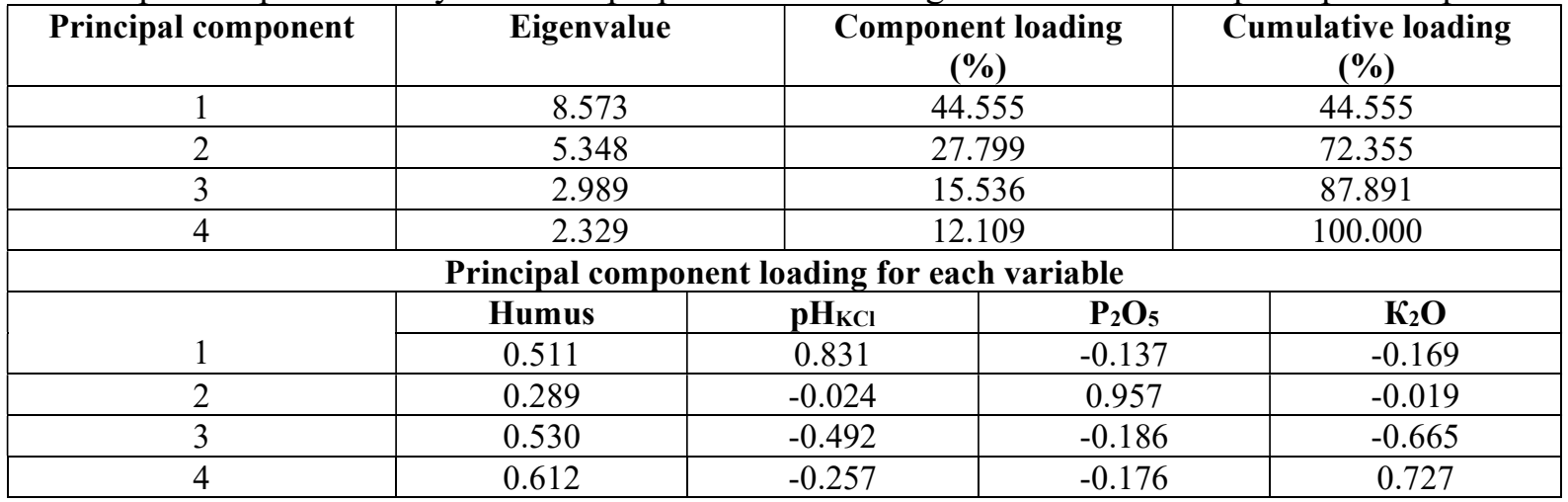

The raster images obtained as a result of multivariate analysis were reclassified and converted into vector layers for the subsequent estimation of the area of the identified zones (Figure 2).
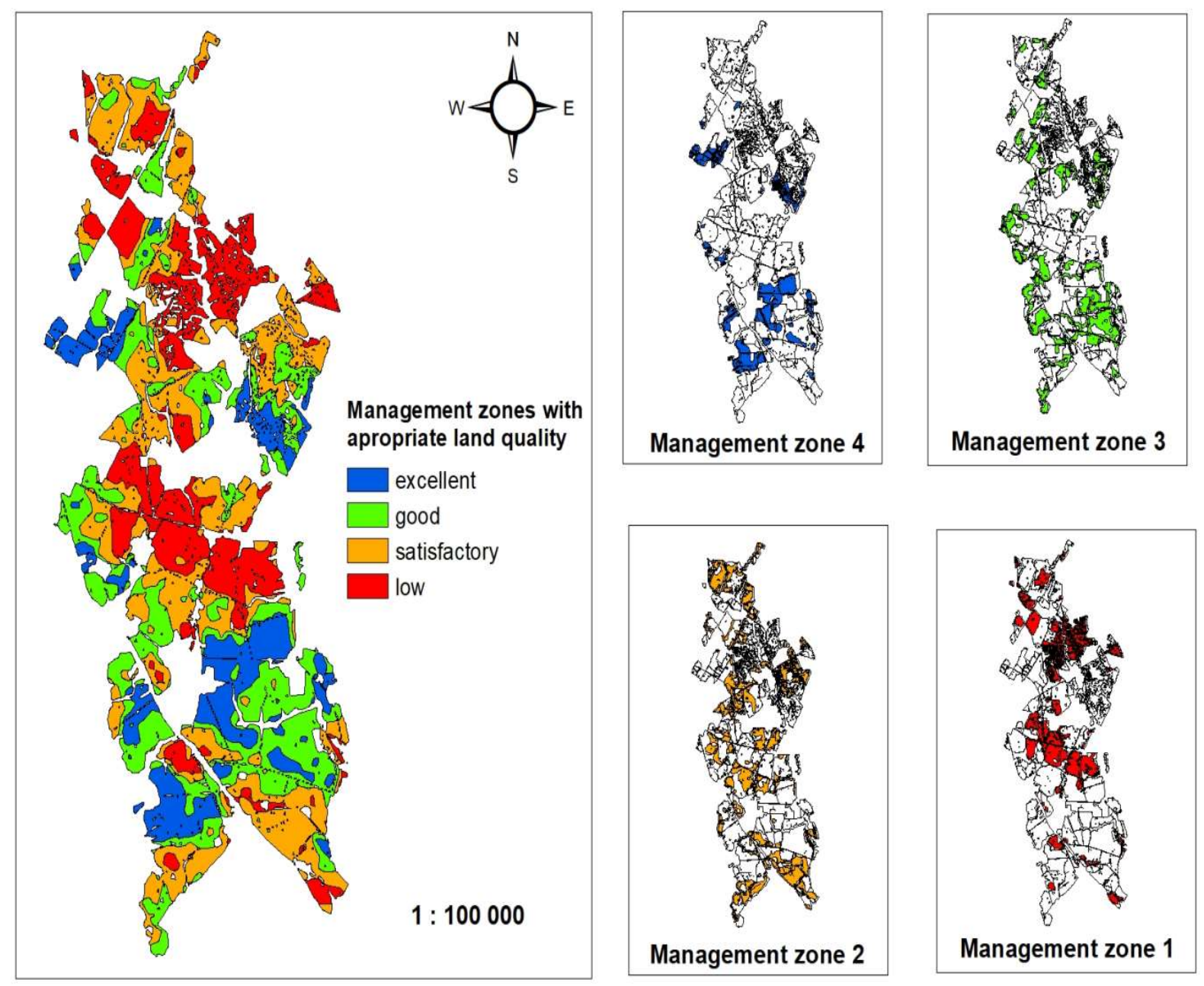

Fig. 2. Identified management zones 
When comparing the areas of the identified zones, the analysis using the method of the main components and that of the functionality of the raster calculator turned out to be almost identical, since the differences with the actual area of the study area were only 16.56 and 16.24 ha, respectively (Table 6). Moreover, all identified zones had a significant coincidence with each other in localization and in area; therefore, both of these methods are suitable for identifying management zones within arable land by a complex of agrochemical and physical-chemical indicators.

Table 6

Identified management zones with the relevant land quality

\begin{tabular}{|c|c|c|c|c|c|c|c|}
\hline \multirow{3}{*}{ } & \multirow{3}{*}{ Land quality } & \multicolumn{2}{|c|}{$\begin{array}{c}\text { Raster, created by } \\
\text { using the } \\
\text { functionality of the } \\
\text { Raster Calculator }\end{array}$} & \multicolumn{2}{|c|}{$\begin{array}{l}\text { Raster, created by } \\
\text { method of Principal } \\
\text { Components }\end{array}$} & \multicolumn{2}{|c|}{$\begin{array}{c}\text { Raster, created by } \\
\text { method of Maximum } \\
\text { Likelihood } \\
\text { Classification } \\
\end{array}$} \\
\hline & & \multicolumn{6}{|c|}{ Zone size } \\
\hline & & hectares & $\begin{array}{l}\% \text { of the } \\
\text { total area }\end{array}$ & hectares & $\begin{array}{l}\% \text { of the } \\
\text { total area }\end{array}$ & hectares & $\begin{array}{c}\text { \% of } \\
\text { the total } \\
\text { area } \\
\end{array}$ \\
\hline 1 & Low & 1977.83 & 23.66 & 1974.35 & 23.62 & 2927.95 & 35.02 \\
\hline 2 & Satisfactory & 2784.07 & 33.31 & 2773.92 & 33.19 & 2379.04 & 28.46 \\
\hline 3 & Good & 2278.11 & 27.26 & 2253.48 & 26.96 & 1106.81 & 13.24 \\
\hline 4 & Excellent & 1318.32 & 15.77 & 1356.91 & 16.23 & 1946.78 & 23.29 \\
\hline \multicolumn{2}{|c|}{ Total area } & 8358.34 & 100.0 & 8358.66 & 100.0 & 8360.58 & 100.0 \\
\hline \multicolumn{2}{|c|}{$\begin{array}{l}\text { Difference with the } \\
\text { reference value }\end{array}$} & +16.24 & $+0,19$ & +16.56 & $+0,20$ & +18.48 & $+0,22$ \\
\hline
\end{tabular}

However, in case of a wider list of indicators, it is more advisable to use the principal component method to identify areas of heterogeneity. It enables to evaluate more completely the available data and find out those that have the maximum variability, and, accordingly, suitability for the delimitation of management zones, which, in particular, is indicated in a number of other works (Nawar at all, 2017; Behera at all, 2018; Mohamed at all, 2019).

Table 7

The mean values of soil properties within the identified management zones

\begin{tabular}{|c|c|c|c|c|c|}
\hline $\begin{array}{c}\text { Management } \\
\text { zone }\end{array}$ & $\begin{array}{c}\text { Number of } \\
\text { parcels }\end{array}$ & Humus, \% & $\mathbf{P}_{2} \mathbf{O}$, $\mathbf{~ m g / k g}$ & $\mathbf{K}_{\mathbf{2}} \mathbf{O}, \mathbf{~ m g} / \mathbf{k g}$ & $\mathbf{p H} \mathbf{K C l}$ \\
\hline 1 & 112 & 2.00 & 120 & 132 & 5.68 \\
\hline 2 & 164 & 2.04 & 183 & 196 & 5.74 \\
\hline 3 & 136 & 2.19 & 251 & 252 & 5.98 \\
\hline 4 & 77 & 2.46 & 322 & 332 & 6.01 \\
\hline
\end{tabular}

Table 7 shows average values of the studied soil properties in each of the four delimited zones, which can be used as input to calculate the rates of fertilizers and chemical reclamants and their differentiated application.

\section{Conclusions and proposals}

The results of the studies indicate that the definition of management zones for the conditions of Belarus can be carried out on the basis of data on the agrochemical and physico-chemical properties of the soil. These data are not always reliable because the methodology for obtaining them is outdated and requires fundamental modernization. This is evidenced by the presence of a significant amount of emissions (46-135 pcs) and a low percentage of their validity when re-checking data (from 38 to $78 \%$ of clusters with high outliers and from 62 to $78 \%$ of clusters with low data outliers were not confirmed). Kriging interpolation (universal for soil $\mathrm{pH}$ and empirical Bayesian for humus, phosphorus, and potassium in the soil) turned out to be the most suitable for modeling the spatial distribution of data on soil parameters. Both the principal component method and the simple summation of interpolated rasters are suitable for identifying management zones (the discrepancy with the actual area was 0.19 and 0.20 percentages, respectively); however, if there are more parameters, preference should still be given to the principal component method. The resulting cartographic image 
with differentiation of management zones can be used for planning differentiated application of mineral fertilizers, which will save resources and improve the chemical, physical and environmental properties of the soil.

\section{References}

1. Bateman I., Jones A., Lovett A. (2002) Applying geographical information systems (GIS) to environmental and resource economics. Environmental and Resource Economics, Vol. 22, pp. 219-269.

2. Behera S.K., Mathur, R.K., Shukla, A.K., Suresh, K., Prakash C. (2018) Spatial variability of soil properties and delineation of soil management zones of oil palm plantations grown in a hot and humid tropical region of southern India. Catena, Vol. 165, pp. 251-259.

3. Daheim C., Poppe K., Schrijver R. (2016) Precision agriculture and the future of farming in Europe. Directorate-General for Parliamentary Research Services. 274 p.

4. Doerge T. A. (1999) Management zone concepts. The site-specific management guidelines. Potash and Phosphate Institute, South Dakota State University, 1999. pp. 1-4.

5. Durdević, B., Jug, I., Jug, D., Bogunović, I., Vukadinović, V., Stipešević, B., Brozović, B. (2019). Spatial variability of soil organic matter content in Eastern Croatia assessed using different interpolation methods. Int. Agrophys., Vol. 33(1), pp. 31-39.

6. Edge B. (2019) An economic-theory-based approach to management zone delineation. In: Poster Proceedings of the 12th European Conference on Precision Agriculture, July 8-11, 2019, Montpellier, France. pp. 56-57.

7. EC (2018) EU agricultural outlook for markets and income, 2018-2030. European Commission, DG Agriculture and Rural Development, Brussels. 128 p.

8. GIS for Housing and Urban Development (2003) The National Academies Press, Washington, 142 p.

9. Kurowska K., Kietlinska E., Kryszk H. (2018) Possibilities use to selected methods of spatial data mining in demographic data analytics. Baltic surveying, Vol. 9, pp. 45-55.

10. Mitchell A. (2005) The ESRI Guide to GIS Analysis. Esri Press, Vol. 2. 252 p.

11. Mohamed S. Metwally, Sameh M. Shaddad, Manqiang Liu, Rong-Jiang Yao, Ahmed I. Abdo, Peng Li; Jiaoguo Jiao, Xiaoyun Chen (2019) Soil properties spatial variability and delineation of site-specific management zones based on soil fertility using fuzzy clustering in a hilly field in Jianyang, Sichuan, China. Sustainability, Vol. 11, issue 24, pp. 1-19.

12. Myslyva T., Sheluto B., Kutsaeva O., Naskova S. (2018) Use of geospatial analysis methods in land management and cadaster. Baltic Surveying, Vol. 9, pp. 56-62.

13. Nawar S., Corstanje R., Halcro G., Mulla D., Mouazen,A.M. (2017) Delineation of soil management zones for variable-rate fertilization: A review. In Advances in Agronomy, Vol. 143, pp. 175-245.

14. Perkins D.D., Larsen C., Brown B.B. (2009) Mapping urban revitalization: using GIS spatial analysis to evaluate a new housing policy. J. Prev. Interv. Community, Vol. 37(1), pp. 48-65.

15. Roudier P., Tisseyre B., Poilvé H., Roger J.M. (2008) Management zone delineation using a modified watershed algorithm. Precision Agriculture, Vol. 9(5), pp. 233-250.

16. Samsonova V.P., Blagoveshchenskii Y.N., Meshalkina, Y.L. (2017) Use of empirical Bayesian kriging for revealing heterogeneities in the distribution of organic carbon on agricultural lands. Eurasian Soil Science, Vol. 50, pp. 305-311.

17. Zarco-Tejada P. J., Hubbard N., Loudjani Ph. (2014) Precision agriculture: an opportunity for EU farmers - potential support with the cap 2014-2020. Joint Research Centre of the European Commission. $57 \mathrm{p}$.

18. Бакланов П. Я., Ермошин В. В., Краснопеев С. М. (2010) Региональные геоинформационные системы в природопользовании на Дальнем Востоке (Regional geographic information systems in nature management in the Far East). Открытое образование, №5, с. 12-23 (in Russian).

19. Барлиани И. Я. (2016) Возможности использования ГИС-технологий в системе планирования и управления территорией (Possibilities of using GIS technologies in the planning and management system of the territory). Интерэкспо Гео-Сибирь, Вып. 6, №1, с. 247-250 (in Russian).

20. Богодяж Е.П. (2019) Национальная система мониторинга окружающей среды Республики Беларусь: результаты наблюдений, 2018 год (National environmental monitoring system of the Republic of Belarus: observations, 2018). Республиканский центр по гидрометеорологии, контролю радиоактивного загрязнения и мониторингу окружающей среды, Минск. 476 с. (in Russian).

21. Каганович А. А. (2017) Планирование территориальной устойчивости с использованием геоинформационных систем (Territorial sustainability planning using geographic information systems). Известия Санкт-Петербургского государственного аграрного университета, №1(46), с. 203-207 (in Russian).

22. Мыслыва Т. Н., Белявский Ю. А. (2019) Геостатистический анализ пространственного распределения агрохимических свойств почв земель сельскохозяйственного назначения (Geostatistical analysis of the spatial distribution of the agrochemical properties of agricultural land). 
Материалы Международной научно-практической конференции «Приемы повышения плодородия почв и эффективности удобрения». БГСХА, Горки, с. 101-103 (in Russian).

23. Сельское хозяйство Республики Беларусь: статистический сборник (2019) (Agriculture of the Republic of Belarus: statistical compilation). Национальный статистический комитет Республики Беларусь, Минск. 212 с. (in Russian).

24. Чымыров А. У., Бектуров А. К. (2013) Использование ГИС в территориальном планировании (Use of GIS in territorial planning). Вестник КГУСТА, №2, с. 124-129 (in Russian).

Information about authors

Tamara Myslyva is a Doctor of Agricultural Sciences, Professor, Head of the Department of Geodesy and Photogrammetry of Belarusian State Agricultural Academy. Her current area of study surrounds the topics of GIS-analysis, GIS-modelling and geospatial statistics. Contact details: Faculty of Land Management, Belarusian State Agricultural Academy, Michurina 5, Gorki, Mogilev region 213407, Republic of Belarus, e-mail: byrty41@yahoo.com, tel: +375 299216839.

Olesya Kutsaeva is a Senior lecturer of the Department of Geodesy and Photogrammetry of Belarusian State Agricultural Academy. Her current area of study surrounds the topics of GIS-analysis, photogrammetry and remote sensing. Contact details: Faculty of Land Management, Belarusian State Agricultural Academy, Michurina 5, Gorki, Mogilev region 213407, Republic of Belarus, e-mail: alexa-1982@bk.ru, tel: +375 2933 21631. 